\title{
EDITORIAL
}

\section{VENEREAL DISEASES IN THE COLONIAL EMPIRE}

That the present issue of this journal is largely concerned with the problem of venereal diseases in the tropics needs no apology. Those who served in tropical areas during the war are well aware of the overwhelming prevalence of these infections in Africa, and in the Middle and Far East, and it is high time that venereologists in Great Britain should begin to interest themselves in the problem in those vast under-developed areas, so many of which are under the British flag.

Thanks to the action of the Nuffield Trust in sponsoring the visits of consultants in various branches of preventive and curative medicine and surgery to the African colonies and protectorates, two members of the M.S.S.V.D. have already completed one series of visits, and together with the Deputy Director of the Colonial Medical Service, himself an experienced colonial doctor, they tell us something of their impressions and their views of the problem.

A recent Colonial Office publication* states that venereal diseases are second only to malaria as a cause of ill-health in East Africa, and that, unlike other diseases, their incidence has risen greatly during and since the late war. Here this immense problem is fundamentally a social one, dependent on such factors as too rapid detribalization, and migration of Africans to towns and areas settled by Europeans, where the prohibition of traditional native family life has led to an increase in prostitution. Since modern treatment can so rapidly and surely arrest the spread of infection, the need for

* "The British Territories in East and Central Africa, 1945-50". June, 1950. Cmd. 7987. H.M.S.O. London. a series of carefully thought-out campaigns planned and controlled by expert venereologists is plainly indicated. Well manned and equipped survey and demonstration teams on the lines of those which have already taken the field in other areas under the auspices of the World Health Organization are a sine qua non if the size and shape of the problem in a given territory is to be accurately gauged. The well-trained registrars available at home would make ideal members of such teams, and the educative value of the vast amount of clinical material would be immeasurable to the traineeconsultant, who would in his turn contribute enthusiasm and clinical discipline to the project. Much of the executive work in such teams could be undertaken by European technicians who could subsequently be permanently employed as V.D. assistants under the control of district medical officers. The eventual employment of such technicians of good ethical standards and with a sound though comparatively inexpensive training, would be both profitable and economical and would do much to conserve medical manpower in the Colonial Medical Service.

A determined effort to stamp out venereal disease, especially the treponematoses, in the empire is already overdue, and, were it made with intelligence, enthusiasm, and reasonable liberality, it could not fail to increase our prestige as a great colonial power. A well-known American colleague coined the aphorism "syphilis is a disease not a disgrace". In Africa this would seem to be not quite true, but the disgrace is not entirely the patient's. 